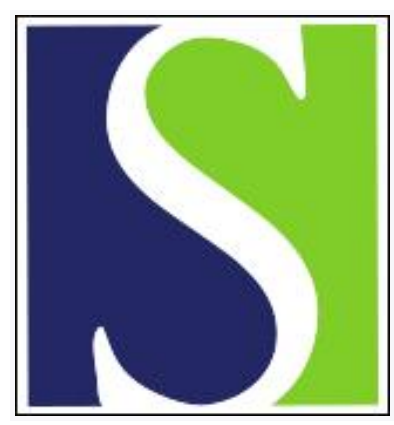

Scand J Work Environ Health 2002;28(6):429-438

https://doi.org/10.5271/sjweh.695

Issue date: Dec 2002

Trends in inhalation exposure to hydrocarbons among commercial painters in The Netherlands

by Burstyn I, Kromhout $\mathrm{H}$

Affiliation: Division of Environmental and Occupational Health, Institute for Risk Assessment Sciences, Utrecht University, Utrecht, Netherlands.

Refers to the following text of the Journal: 2001;27(5):335-342

Key terms: commercial painter; database; determinants of exposure; exposure assessment; health surveillance; hydrocarbons; inhalation exposure; mixed-effects model; Netherlands; nonlinear regression; single-cell model; solvent; toluene

This article in PubMed: www.ncbi.nlm.nih.gov/pubmed/12539803 


\title{
Trends in inhalation exposure to hydrocarbons among commercial painters in The Netherlands
}

\author{
by Igor Burstyn, PhD, ${ }^{1}$ Hans Kromhout, $P h D^{1}$
}

Burstyn I, Kromhout $\mathrm{H}$. Trends in inhalation exposure to hydrocarbons among commercial painters in The Netherlands. Scand J Work Environ Health 2002;28(6):429-438.

Objectives An attempt was made to develop a database for measurements of exposure to solvents that could be used as a tool in the historical exposure assessment of commercial painters participating in a health surveillance program.

Methods The measurement data on personal exposure from six studies still available for Dutch commercial painters were collected into a database. The database was analyzed to identify time trends for the inhalation exposure levels of hydrocarbons and the production conditions that influence exposure levels among commercial painters in The Netherlands.

Results Altogether 304 measurements of solvent exposure were collected between 1980 and 1999, providing data for 137 workers. Toluene was selected as a marker for solvent exposure, since hydrocarbon exposures appeared to be strongly correlated. Exposure to toluene measured during the application of solvent-based paints has declined by $12 \%$ per year. The use of solvent-based paints, painting in small rooms, house (versus shipyard) painting, and spray-painting were associated with increased exposures. Water-based paint was also associated with increased exposure to toluene, relative to tasks in which no paint was used. The exposure model for toluene explained $86 \%$ of the between-worker variance. In a subset of the data, we observed that a single cell model did not adequately describe total solvent exposure among painters, because of the stronger-than-expected positive effect of source strength and the lack of the protective effect of general ventilation.

Conclusions An exposure model was developed that can be used to predict the intensity of inhalation exposure to aromatic solvents among commercial painters in The Netherlands.

Key terms database, determinants of exposure, exposure assessment, health surveillance, mixed-effects models, nonlinear regression, single-cell model, solvents, toluene.

In 1995, ARBOUW (the Dutch National Institute for Occupational Safety and Health in the Construction Industry) started a health surveillance program designed to follow the health of commercial painters prospectively in The Netherlands. Part of the reason for establishing the program was the evidence that chronic toxic encephalopathy (1-3), hearing loss (4), decreased semen quality (5), neuroblastoma in offspring (6), neurological deficits (7), neurobehavioral symptoms (8-10), dementia (11), and decreased respiratory function (eg, airflow obstruction) (12) have been associated with exposure to hydrocarbons among painters in previous stud- ies. A case study of three painters with 25 to 46 years of exposure to solvents, presenting symptoms of Parkinson syndrome with pyromidal features, was described in The Netherlands in 1999 (13). These health effects may be mediated through the oxidation of lipid tissues in response to the inhalation of paint thinners (14). Therefore, one of the goals of the health surveillance program among commercial painters in the construction industry is to investigate the relationship between long-term exposure to organic solvents and chronic toxic encephalopathy. An integral part of the effort to reach this objective is the reconstruction of past

1 Division of Environmental and Occupational Health, Institute for Risk Assessment Sciences, Utrecht University, Utrecht, The Netherlands.

Reprint requests to: Dr Hans Kromhout, Institute for Risk Assessment Sciences, Utrecht University, PO Box 80176, NL-3508 TD Utrecht, The Netherlands. [E-mail: h.kromhout@iras.uu.nl] 
hydrocarbon solvent exposures among these painters. We set out to develop a database of exposure measurements that can be used as a tool for assessing exposure among commercial painters in The Netherlands. This database was analyzed to identify (i) time trends for the levels of inhalation exposure to hydrocarbons and (ii) production conditions that influence exposure levels among commercial painters in The Netherlands.

\section{Material and methods}

\section{Building the exposure database}

Seven studies were identified that had sufficiently detailed information on airborne exposure levels among commercial painters for inclusion in the database. These studies were selected after the peer-reviewed scientific literature and internal reports from leading research institutions in the field of occupational hygiene in The Netherlands were consulted. The data from one of the 1991 surveys were lost, leaving only six studies to be included in the database (15-20). A database management system was created using a Microsoft Access 97 application to allow the collection, storage, and retrieval of data from these studies. We coded contextual information from the narrative descriptions of the workplaces from which measurements were collected, the narrative descriptions having been supplied by the authors in the original reports. Coding was done with reliance on our judgment and in consultation with some of the original investigators and representatives of trade unions and employers (ARBOUW). Contextual information was coded into categories that were used in the modeling. These categories were analogous to the data collected periodically from commercial painters as part of the health surveillance program. The amount, type, and quality of contextual information varied considerably among the surveys. The data collected comprise most exposure measurements among commercial painters still available in The Netherlands. Only personal measurements were considered in the analysis.

\section{Statistics}

All the analyses were carried out using SAS version 6.12 software (SAS Institute, Cary, North Carolina, United States). Mixed-effects models were evaluated using PROC MIXED, and a nonlinear ordinary least square model was fit with PROC MODEL.

\section{Analysis of historical exposure trends}

Descriptive statistics. All the concentrations reported to have been below the limit of detection were replaced with values equal to half of the concentration given in the original reports (ie, half of the estimated method limit of detection). The potential dependent variables were selected from the airborne concentrations of the chemical agents measured in each survey. Because we aimed to pool data across data sets, we selected agents that were measured in as many surveys and samples as possible. Furthermore, we attempted to ensure that the list of dependent variables included chemicals from different groups of organic chemicals (eg, aromatic and aliphatic hydrocarbons). Exposure levels were summarized in terms of averages, ranges, geometric means (GM) and geometric standard deviations (GSD). Frequency histograms and normal probability plots were examined to determine the appropriateness of logarithmic transformation (base e) in normalizing the dependent variables.

Selection of the dependent variables. The correlation among the potential dependent variables was examined using both a Pearson correlation and a principal component analysis (with Varimax rotation). Only the principal components with eigenvalues greater than 1 were considered significant (ie, explaining more multiple correlation than a single hydrocarbon concentration). $\mathrm{Nu}-$ merical indices representing each principal component were generated as principal component scores. Individual hydrocarbons were selected as dependent variables only if they were distributed among the predictor variables in such a manner as to allow their estimation (eg, they had to have been measured in every period). These were dependent variables in the mixed-effects models (equation 1).

Modeling exposure trends and determinants. Prior to fitting the mixed-effects models, we examined the correlation among the predictor variables in order to identify predictors that may cause multicolinearity: correlation coefficient $\geq 0.70$. Only one of the correlated predictor variables was used in the analyses. Mixed-effects models were constructed to identify trends in exposure among all the exposure measurements gathered into the database. They had the following general form:

$$
Y_{i j \mid \beta 1, \beta 2, \ldots \beta k}=\mu+\beta_{1}+\beta_{2}+\ldots \beta_{k}+\chi_{i}+\varepsilon_{i j},
$$

where $Y_{i j \mid \beta 1, \beta 2, \ldots \beta k}=$ the natural logarithm of the exposure concentration measured on the $j^{\text {th }}$ day of the $i^{\text {th }}$ worker in the presence of $k$ exposure determinant; $\mu=$ the true mean of log-transformed exposure averaged over all strata; $\beta_{1}, \beta_{2}, \ldots \beta_{k}=$ fixed effects of the $k$ exposure determinant; $\chi_{i}=$ the random effect of the $i^{\text {th }}$ worker; and $\varepsilon_{i j}=$ the random within-worker day-to-day variation.

The model assumes that $\chi_{i}$, and $\varepsilon_{i j}$ are normally distributed with zero means and variances ${ }_{B W} \sigma_{y}^{2}$ and ${ }_{W W} \sigma_{y}^{2}$, 
respectively, which are mutually independent. These variances are estimated as between-worker $\left.{ }_{B W} S_{y}{ }^{2}\right)$ and day-to-day $\left({ }_{w w} S_{y}{ }^{2}\right)$ covariance components.

Potential determinants of exposure $\left(\beta_{1}, \beta_{2}, \ldots \beta_{k}\right)$, such as time-trend, types of paint and application method used, location of a job, and sampling strategy, were treated as fixed effects, since they were selected for the study, instead of being randomly sampled. Worker was treated as a random effect, since workers were selected from all commercial painters, and there were multiple measurements from individual painters in some surveys. The between- and within-worker variance components were pooled across all the determinants of exposure and were assumed to follow a compound symmetry covariance structure. The restricted maximum likelihood method was used to fit the models. Only fixed effects with a significance of $<0.05$ were considered in the interpretation of the models. An assumption of homoscedasticity was tested via residual plots (predicted values versus standardized residual).

\section{Evaluation of the deterministic single-cell model for painters}

A single-cell model assumes that a steady-state concentration has been reached in the work environment. It is summarized by the following equation (21):

$$
E=S \times Q^{-1},
$$

where $E=$ the steady-state concentration $\left(\mathrm{mg} / \mathrm{m}^{3}\right), S=$ the source strength $(\mathrm{mg} / \mathrm{s})$, and $Q=$ the ventilation rate $\left(\mathrm{m}^{3} / \mathrm{s}\right)$. This equation can be parameterized as:

$$
E=S^{\beta 1} \times Q^{\beta 2},
$$

with the hypotheses of interest being whether $\beta_{1}=1$ and $\beta_{2}=-1$. Equation 3 can be fit to the data set with estimated $E, S$, and $Q$ using nonlinear ordinary least squares. (See appendix 1 for the SAS 6.12 code.)

In one of the data sets recovered for the database, in addition to total hydrocarbon exposure, source strength and ventilation rate had been estimated on the basis of detailed information on the amounts and types of paints used and also measured ventilation. This information allowed us to evaluate the appropriateness of the single-cell exposure model for painters. Source strength was estimated using information provided by painters: the surface area painted (meters squared) and the amount of thinner, cement and filler used (all in liters) during exposure monitoring. The following assumptions were made based on reports of the Vereniging van Verf en Drukinktfabrikanten, an association of paint and printing ink producers and suppliers in The Netherlands (http://www.vvvf.nl). It was first assumed that the solvents had an average density of $0.9 \mathrm{~kg} / \mathrm{l}$. Next, the mass of the solvents used in the paints was calculated on the assumption that (i) with 1 liter of paint $10 \mathrm{~m}^{2}$ of surface could be covered and that (ii) alkyd paint contained $50 \%$ solvents, rapid primer contained $60 \%$ solvents, acrylate paints contained $8 \%$ solvents, and latex paint contained $4 \%$ solvents. The mass of solvents used from other sources was estimated on the assumption of the following solvent content of the specific materials: thinner, 100\%; alkyd resin-based cement and filler, $25 \%$; cement and filler on acrylate base, $4 \%$; and wallpaper paste, $0.5 \%$. Dividing the sum of both sources of solvents by the sampling duration produced an estimate of source strength (milligrams of solvents per second). The ventilation rate was estimated on the basis of measurements of incoming and outgoing airflow in the rooms where painting took place. Air velocities, dimensions of the ventilation gaps (identified with smoke tubes), and the volume of the room were measured and used to estimate the ventilation rate.

\section{Results}

\section{Historical trends in exposure}

Altogether 304 measurements of solvent exposure were collected between 1980 and 1999, providing data from 137 workers. Measurements of more than 4000 concentrations of individual chemicals were collected. Most of the measurements were collected during the application of solvent-based paints, with the use of randomized sampling strategies (table 1). Measurements during the application of solvent-based, but not water-based, paints were available for all the periods, and therefore we were able to estimate the time trends of exposure due to the use of solvent-based paints only. Data were available for painting done in houses and shipyards, during spray-painting and manual painting with a brush, a roller, or a brush and a roller.

The solvents most commonly measured among Dutch commercial painters were toluene, xylene, ethylbenzene, n-decane, and n-hexane, and these solvents were consequently used as markers for the solvent exposure of these workers. These levels are summarized in table 2. Concentrations of these hydrocarbons followed frequency distributions well approximated by $\log$ normal distributions, and thus all the subsequent analyses were performed with log-transformed concentrations. Inhalation exposure levels for selected hydrocarbons were summarized for different types of paint, as well as across all paint types. Toluene exposure showed the largest variability, with a geometric standard deviation on the order of 9 to 10 for solvent-based paints and 7 for water-based paints. n-Hexane exposures showed the least amount of variability, especially 
Table 1. Description of data sets collected into a database on historical exposures among commercial painters in The Netherlands.

\begin{tabular}{|c|c|c|c|c|c|c|c|c|c|c|c|c|}
\hline \multirow[t]{2}{*}{ Year } & \multicolumn{4}{|c|}{$\begin{array}{l}\text { Samples collected during } \\
\text { use of different paints }\end{array}$} & \multirow[t]{2}{*}{$\begin{array}{l}\text { Spray- } \\
\text { painting c }\end{array}$} & \multirow[t]{2}{*}{ Workers } & \multirow[t]{2}{*}{$\begin{array}{l}\text { Sampling } \\
\text { days }\end{array}$} & \multicolumn{3}{|c|}{ Sampling strategy } & \multirow[t]{2}{*}{ Location } & \multirow{2}{*}{$\begin{array}{l}\text { Average samp- } \\
\text { ling duration } \\
\text { (minutes) }\end{array}$} \\
\hline & All & $\begin{array}{l}\text { Solvent } \\
\text { based }^{a}\end{array}$ & $\begin{array}{l}\text { High solid } \\
\text { or 2-com- } \\
\text { ponent }\end{array}$ & $\begin{array}{l}\text { Water- } \\
\text { based }{ }^{b}\end{array}$ & & & & $\begin{array}{l}\text { Random } \\
\text { day }\end{array}$ & $\begin{array}{l}\text { Random } \\
\text { worker }\end{array}$ & Other features & & \\
\hline 1980 & 45 & 39 & $5^{\mathrm{d}}$ & 1 & 5 & 45 & 12 & Yes & Yes & Random & House & Full shift \\
\hline 1982-1983 & 22 & 22 & - & - & - & 21 & 20 & No & No & Worst case & House & 221 \\
\hline 1984 & 4 & 4 & - & - & 2 & 2 & 2 & Yes & No & Task-based & Shipyard & 168 \\
\hline 1994 & 95 & 47 & - & 42 & - & 33 & 19 & Yes & Yes & $\begin{array}{l}\text { Avoid consecutive } \\
\text { days; all workers } \\
\text { available }\end{array}$ & House & 215 \\
\hline 1998 & 10 & 10 & - & - & - & 6 & 3 & Yes & Yes & Random & House & 176 \\
\hline 1999 & 128 & 25 & 44 & 6 & 24 & 30 & 53 & Yes & Yes & $\begin{array}{l}\text { Four measurement } \\
\text { periods/year }\end{array}$ & Shipyard & 461 \\
\hline
\end{tabular}

${ }^{a}$ Alkyd-based, synthetic wall paints, traditional turpentine paints, chloro-rubber, and nonspecified solvent-based paints.

b Acrylate.

c Number of samples collected during spray-painting (versus manual painting with roller or brush).

d Two-component paint only, since high-solid paint was only introduced in the 1990s.

Table 2. Exposure levels during the use of different paints. (AM = arithmetic mean, GM = geometric mean, GSD = geometric standard deviation)

\begin{tabular}{|c|c|c|c|c|c|}
\hline Paint type & $\mathrm{Na}^{\mathrm{a}}$ & $\mathrm{AM}\left(\mathrm{mg} / \mathrm{m}^{3}\right)$ & $\mathrm{GM}\left(\mathrm{mg} / \mathrm{m}^{3}\right)$ & GSD & Range $\left(\mathrm{mg} / \mathrm{m}^{3}\right)$ \\
\hline \multicolumn{6}{|l|}{ All } \\
\hline Toluene & 304 & 1.06 & 0.09 & 11.47 & $0.004-43.00$ \\
\hline Xylene ${ }^{b}$ & 259 & 11.47 & 1.55 & 9.37 & $0.005-391.72$ \\
\hline Ethylbenzene & 259 & 2.87 & 0.30 & 11.94 & $0.002-86.00$ \\
\hline n-Hexane & 223 & 0.10 & 0.01 & 4.06 & $0.007-10.93$ \\
\hline n-Decane & 245 & 5.85 & 0.43 & 13.87 & $0.005-210.00$ \\
\hline \multicolumn{6}{|c|}{ Water-based (acrylate) } \\
\hline Toluene & 49 & 0.61 & 0.12 & 7.24 & $0.004-\quad 9.43$ \\
\hline Xylene $^{\mathrm{b}}$ & 48 & 1.15 & 0.30 & 6.17 & $0.011-13.13$ \\
\hline Ethylbenzene & 48 & 0.23 & 0.05 & 8.67 & $0.002-\quad 1.73$ \\
\hline n-Hexane & 48 & 0.04 & 0.03 & 2.22 & $0.007-\quad 0.33$ \\
\hline n-Decane & 48 & 1.75 & 0.57 & 5.42 & $0.010-23.46$ \\
\hline \multicolumn{6}{|c|}{ High-solid ( $\mathrm{N}=11)$ and two-component $(\mathrm{N}=38)$} \\
\hline Toluene & 49 & 0.47 & 0.05 & 9.78 & $0.004-\quad 4.00$ \\
\hline Xylene $^{\mathrm{b}}$ & 44 & 25.99 & 5.64 & 6.49 & $0.094-391.72$ \\
\hline Ethylbenzene & 44 & 3.86 & 1.02 & 6.05 & $0.021-42.32$ \\
\hline n-Hexane & 44 & 0.08 & 0.01 & 4.85 & $0.007-1.62$ \\
\hline n-Decane & 44 & 0.50 & 0.13 & 5.99 & $0.005-\quad 4.80$ \\
\hline \multicolumn{6}{|c|}{ Other solvent-based ${ }^{c}$} \\
\hline Toluene & 147 & 1.93 & 0.24 & 8.94 & $0.004-43.00$ \\
\hline Xylene ${ }^{b}$ & 108 & 15.26 & 4.31 & 5.16 & $0.085-233.50$ \\
\hline Ethylbenzene & 108 & 4.95 & 1.04 & 6.36 & $0.023-86.00$ \\
\hline n-Hexane & 72 & 0.20 & 0.02 & 4.26 & $0.007-10.94$ \\
\hline n-Decane & 94 & 13.90 & 2.69 & 8.76 & $0.006-210.00$ \\
\hline
\end{tabular}

a Sample size.

${ }^{b}$ Sum of othro-, para- and meta-xylene.

${ }^{c}$ Alkyd-based $(\mathrm{N}=116)$, synthetic wall paints $(\mathrm{N}=8)$, traditional turpentine paints $(\mathrm{N}=4)$, chloro-rubber $(\mathrm{N}=16)$, and nonspecified solvent-based $(\mathrm{N}=3)$ paints.

during the application of water-based paint (GSD 2.22) versus solvent-based paints (GSD on the order of 4 to 5). Xylene and ethyl-benzene concentrations tended to be higher during the application of solvent-based paints. Patterns of exposure levels for toluene, n-hexane, and n-decane did not indicate clear differences between those for water-based and solvent-based paints. The Dutch occupational exposure limit for toluene (150 $\mathrm{mg} / \mathrm{m}^{3}$ ) was not exceeded in any of the measurements.
However, the xylene exposure limit of $210 \mathrm{mg} / \mathrm{m}^{3}$ was exceeded in two measurements, which were collected during painting with solvent-based paints.

Examination of the correlation among selected hydrocarbon concentrations in the air revealed that only xylene and ethyl-benzene were highly correlated (table 3). However, there was a weak-to-moderate positive correlation among the pairs of all five hydrocarbons (toluene, xylene, ethyl-benzene, n-decane, and n-hexane). 
A principal component analysis revealed that two sources of variability accounted for $79 \%$ of the multiple correlation among the selected hydrocarbons (table 4). The first principal component was approximately equally positively associated, as judged by the eigenvector, with all five hydrocarbons. The second principal component was primarily positively associated with n-hexane and negatively associated with xylene and ethyl-benzene. When separate principal component analyses were repeated for different paint types, they revealed the same pattern as for the pooled data (not shown).

On the basis of these considerations, and taking into account the distribution of individual hydrocarbon concentrations, three dependent variables were selected for modeling historical exposure trends. These were the natural logarithm of the toluene concentration and the scores of the first and second principal components (computed as eigenvector-weighted sums of the natural logarithms of the exposure concentrations for the five hydrocarbons). The results of the mixed effects modeling (table 5) indicated that, between 1980 and 1999, the toluene exposures measured during the application of solvent-based paints declined by an average of $12 \%$ per year, equivalent to the halving of the exposure levels approximately every 5.5 years. Solventbased paints were associated with an approximately 17 times greater toluene exposure relative to the circumstances in which paints were not used (eg, clean-up or preparation of surfaces for painting). Water-based paints were associated with approximately doubled toluene exposure relative to the circumstances in which no paints were used. As could have been expected, the samples collected in small rooms $(<50$ $\mathrm{m}^{3}$, also identified as worst-case sampling in one survey), were associated with a near-doubling of the toluene concentration when compared with samples collected in large rooms and outdoors. House painting was associated with a ninefold increase in toluene concentration relative to shipyard painting (on the assumption of a similar type of application). Spray-painting was associated with a fivefold increase in toluene exposure relative to manual painting. The presence of local exhaust ventilation was not retained in the final model, because of confounding; it was associated with higher exposure concentrations and negation of the effect of small room volume. The toluene exposure model explained most of the between-worker variance (86\%), reducing the residual range within which $95 \%$ of the average exposure concentrations for individual workers were likely to fall $\left.{ }_{\mathrm{B} W} \mathrm{R}_{0.95}(22)\right]$ from 1580 to 16. However, the substantial day-to-day (within-worker) variance remained unexplained by our model. Both the between- and within-worker variance components estimated in the mixed-effects model differed significantly from zero. The trends in exposure to toluene dur-
Table 3. Pair-wise Pearson correlation for exposure levels to five hydrocarbons (subjected to natural logarithm transformation) measured during commercial painting (all $\mathrm{P}<0.0001$ unless otherwise specified, 223 observations).

\begin{tabular}{lcccc}
\hline Hydrocarbon & Xylene & Ethylbenzene & $\mathrm{n}$-Hexane & $\mathrm{n}$-Decane \\
\hline Toluene & 0.37 & 0.34 & 0.54 & 0.40 \\
Xylene &. & 0.97 & $0.12^{\mathrm{a}}$ & 0.38 \\
Ethylbenzene &. &. & $0.12^{\mathrm{a}}$ & 0.41 \\
n-Hexane &. &. &. & 0.34 \\
\hline
\end{tabular}

a $\mathrm{P}<0.08$

Table 4. Results of the principal component analysis of multiple correlation for the exposure levels to five hydrocarbons (subjected to natural logarithm transformation) measured during commercial painting. Varimax rotation was used; only principal components with an eigenvalue of $>1$ are shown (223 observations).

\begin{tabular}{lcc}
\hline & $\begin{array}{c}\text { First principal } \\
\text { component }\end{array}$ & $\begin{array}{c}\text { Second principal } \\
\text { component }\end{array}$ \\
\cline { 2 - 3 } & $\begin{array}{c}\text { Eigenvalue } \\
\text { (variance explained) }\end{array}$ & $\begin{array}{c}\text { Eigenvalue } \\
\text { (variance explained) }\end{array}$ \\
\cline { 2 - 3 } Hydrocarbon & $2.65(53 \%)$ & $1.28(26 \%)$ \\
\cline { 2 - 3 } & Eigenvector & Eigenvector \\
Toluene & 0.43 & 0.42 \\
Eylene & 0.52 & -0.43 \\
n-Hexane & 0.52 & -0.43 \\
n-Decane & 0.30 & 0.65 \\
& 0.42 & 0.18 \\
\hline
\end{tabular}

ing the predominant use of solvent-based paints in large rooms or outdoors predicted by our models are illustrated in figure 1.

Regression coefficients for the predictors of the scores of the principal components followed a slightly different pattern than that of toluene (table 5). It should be noted that these were estimated from a smaller subset of the overall data and thus cannot be expected to be identical to those observed for toluene. Nonetheless, the first principal component was strongly associated with a historical decline in exposure levels during the application of solvent-based paints. It was also strongly positively associated with the application of solventbased paint and spray-painting. On the other hand, the score of the second principal component revealed neither time trends nor an association with the use of solvent-based paints. It was, however, positively associated with spray-painting and house-painting with waterbased paints.

None of the mixed-effects models indicated deviations from the assumption of homoscedasticity, as indicated by the residual plots.

\section{Deterministic single-cell model}

From the database, we extracted 77 observations that were suitable for evaluating a deterministic 
Table 5. Determinants of exposure to hydrocarbons (fixed effects) among commercial painters — results of the mixed effects models with worker as a random effect and with a compound symmetry covariance structure.

\begin{tabular}{|c|c|c|c|c|c|c|c|c|c|c|c|}
\hline \multirow[t]{2}{*}{ Determinant of exposure } & \multicolumn{5}{|c|}{$\mathrm{Ln}\left(\mathrm{mg} / \mathrm{m}^{3} \text { toluene }\right)^{\mathrm{a}}$} & \multicolumn{3}{|c|}{ First principal component ${ }^{b}$} & \multicolumn{3}{|c|}{ Second principal component ${ }^{b}$} \\
\hline & $\begin{array}{l}\text { Range or } \\
\text { count }^{c}\end{array}$ & $\beta^{d}$ & $\mathrm{SE}^{\mathrm{e}}$ & $P(\beta \neq 0)^{f}$ & $\begin{array}{l}\text { Range or } \\
\text { count }^{c}\end{array}$ & $\beta^{d}$ & SE ${ }^{e}$ & $P(\beta \neq 0)^{\dagger}$ & $\beta^{d}$ & $\mathrm{SE}^{\mathrm{e}}$ & $P(\beta \neq 0)^{f}$ \\
\hline Intercept & . & $-2.84^{g}$ & 0.36 & 0.0001 & . & -0.44 & 0.41 & 0.28 & 0.82 & 0.26 & 0.003 \\
\hline $\begin{array}{l}\text { Year (since 1980) } \times \\
\text { solvent-based paint }\end{array}$ & $0-19$ & -0.12 & 0.02 & 0.0001 & $14-19$ & -0.30 & 0.10 & 0.004 & 0.10 & 0.07 & 0.15 \\
\hline $\begin{array}{l}\text { Solvent-based paint (1) } \\
\text { versus no paint (0) }\end{array}$ & 196 & 2.82 & 0.44 & 0.0001 & 116 & 5.92 & 1.83 & 0.002 & -1.86 & 1.19 & 0.12 \\
\hline $\begin{array}{l}\text { Water-based paint ( } 1) \\
\text { versus no paint }(0)\end{array}$ & 49 & 0.74 & 0.41 & 0.07 & 48 & 0.31 & 0.38 & 0.4 & 0.43 & 0.25 & 0.09 \\
\hline $\begin{array}{l}\text { Small room (1) versus } \\
\text { large room or outdoors (0) }\end{array}$ & 100 & 0.45 & 0.25 & 0.07 & - & . & . & . & . & . & . \\
\hline $\begin{array}{l}\text { Shipyard painting (1) } \\
\text { versus house painting (0) }\end{array}$ & 132 & -2.25 & 0.36 & 0.0001 & 128 & -0.35 & 0.44 & 0.4 & -1.51 & 0.27 & 0.0001 \\
\hline $\begin{array}{l}\text { Spray-painting (1) } \\
\text { versus manual painting (0) }\end{array}$ & 31 & 1.68 & 0.39 & 0.0001 & 24 & 1.41 & 0.38 & 0.0003 & 0.68 & 0.22 & 0.003 \\
\hline Covariance components & & $\begin{array}{l}\text { Estimate } \\
(\% \text { explained } \\
\left.\text { by model }{ }^{n}\right)\end{array}$ & $\mathrm{SE}^{\mathrm{e}}$ & $\mathrm{Pi}^{\mathrm{i}}$ & & $\begin{array}{l}\text { Estimate } \\
(\% \text { explained } \\
\left.\text { by model }{ }^{h}\right)\end{array}$ & SE ${ }^{e}$ & $P^{i}$ & $\begin{array}{l}\text { Estimate } \\
(\% \text { explained } \\
\left.\text { by model }{ }^{h}\right)\end{array}$ & $\mathrm{SE}^{\mathrm{e}}$ & $P^{i}$ \\
\hline Between worker & & $0.49(86)$ & 0.18 & 0.0070 & & $0.66(50)$ & 0.2 & 0.0009 & $0.11(85)$ & 0.06 & 0.0700 \\
\hline Within worker (day-to-day) & & $2.22(11)$ & 0.22 & 0.0001 & & $1.28(2)$ & 0.1 & 0.0001 & $0.62(0)$ & 0.07 & 0.0001 \\
\hline
\end{tabular}

a 304 measurements and 137 workers.

b 223 measurements and 63 workers.

" For the determinants of exposure, counts for dummy variables (number of "yes") and ranges for continuous variables, different sets of values existed

for the model based on toluene exposure and the two models based on the scores of the first two principal components as dependent variables.

d Regression coefficient for fixed effect.

${ }^{\text {e }} \mathrm{SE}$ is the standard error of $\beta$ or the estimate of the covariance component.

f Student's t-test for the fixed effect.

${ }^{9}$ Exposures when paint was not used ( $\mathrm{N}=59$ for toluene exposure), during manual house painting under representative conditions.

h Percentage of the covariance component explained, relative to the model with only random worker effect.

i P-value of the Wald test for the covariance component being equal to zero.

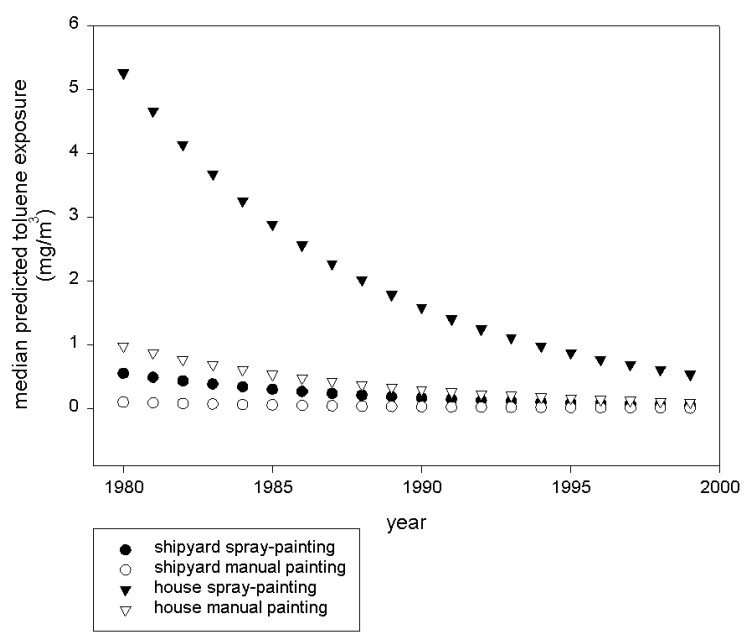

Figure 1. Predicted trends in exposure of commercial painters to toluene during the application of solvent-based paints either in large rooms $\left(>50 \mathrm{~m}^{3}\right)$ or outdoors.

single-cell model. For these observations, total hydrocarbon exposure (n-hexane, toluene, ethyl-benzene, $\mathrm{o}-/ \mathrm{p}-/ \mathrm{m}$-xylene, styrene, n-nonane, 3-ethyl-toluene, 4-ethyl-toluene, and n-decane) had an arithmetic mean of $32.96 \mathrm{mg} / \mathrm{m}^{3}$, a median of $20.27 \mathrm{mg} / \mathrm{m}^{3}$, and a range of $0.03-242.29 \mathrm{mg} / \mathrm{m}^{3}$; the estimated source strength had an arithmetic mean of $13.92 \mathrm{mg} / \mathrm{s}$, a median of 9.23 $\mathrm{mg} / \mathrm{s}$, and a range of $0.59-79.76 \mathrm{mg} / \mathrm{s}$; the estimated ventilation rate had an arithmetic mean of $0.71 \mathrm{~m}^{3} / \mathrm{s}$, a median of $0.31 \mathrm{~m}^{3} / \mathrm{s}$, and a range of $0.03-3.50 \mathrm{~m}^{3} / \mathrm{s}$.

The nonlinear ordinary least-square estimation procedure revealed that equation 3 explained the variation in the total hydrocarbon exposure concentrations very well, as judged by an adjusted $\mathrm{R}^{2}$ of 0.76 . However, the parameter estimates differed from those expected with a single-cell model, equation 2 . Thus $\beta_{1}$ was estimated to be 1.26 (approximate standard error 0.01 ), and $\beta_{2}$ was estimated to be 0.13 (approximate standard error 0.07). Assuming a normal distribution of the parameters, we obtained the following approximate $95 \%$ confidence intervals (95\% CI): $1.24-1.28$ for $\beta_{1}$ and $-0.01-0.27$ for $\beta_{2}$. Therefore, the hypotheses that $\beta_{1}=1$ and $\beta_{2}=-1$ could be rejected with $95 \%$ confidence. In addition, Wald tests indicated that the probabilities that $\beta_{1}=1$ and $\beta_{2}=-1$ were both only 0.0001 . There was no relationship between the predicted values and residuals 
from the model. The residuals followed a symmetric frequency distribution that resembled a Gaussian normal distribution.

\section{Discussion}

Our study is the first attempt to use historical exposure measurements to model determinants of exposure among commercial painters, and it is the first report of an exposure database specifically developed to support a health surveillance program among commercial painters. Previous attempts to model long-term exposures to mixed solvents among painters either relied on an expert assessment approach or simply used duration of exposure as a surrogate of dose (23). However, quantitative exposure estimates that recognize time trends in exposure are needed to facilitate exposure-response modeling and accurate risk assessment through longitudinal studies.

Toluene appears to be a promising proxy for aromatic hydrocarbon solvent exposure, since it appeared to correlate well with other aromatic hydrocarbons and showed similar associations with determinants of exposure as the score of the first principal component. However, our data was limited in its ability to explore the relation between aromatic and aliphatic hydrocarbons, since aliphatic hydrocarbons (such as n-hexane) were not monitored in all the production circumstances where toluene was determined. Thus it is recommended that the relationship between aliphatic and aromatic hydrocarbon exposure during painting be explored in future studies. Such studies are especially important in that we identified a significant second principal component among the hydrocarbon exposures, and this finding indicates that the relative composition of hydrocarbon emissions can vary substantially among different production circumstances.

We observed that exposure levels of painters using solvent-based paints have declined by a factor of 11 over a 20-year period in The Netherlands. This reduction reflects the decline in the solvent content of the solventbased paints and the introduction of water-based paints that have become more widely used since the 1990s. A historical decline in exposures to solvents among painters has been reported recently, but not quantified (24). Furthermore, distinct differences in exposure were detected between solvent- and water-based paints, between shipyard and house painting, and between spray and manual (with roller or brush) painting. The effect of spray-painting observed in our study was approximately two times greater than that suggested by "experienced industrial hygienists" (5 versus 2-2.5) (23). The intensity of exposure during a given time period, the location, and the type of application can be estimated directly from our toluene exposure model. (See appendix 2.) Information on exposure intensity would have to be combined with data on exposure duration to derive cumulative and career-average indices of exposure for studies on health effects. We have confidence in our estimates of exposure intensity, since the model on which they are based explained most of the betweenworker variability.

In any exposure assessment that applies our results, the modeled estimates for exposure intensity would have to be adjusted for the use of respiratory protective equipment in estimates of solvent exposure for painters in the surveillance program. To achieve this goal, we propose that the following previously estimated protection factors for painters exposed to mixed solvents be used: 0 for dust masks, 0.65 for cartridges, and 0.90 for supplied air respirators (23).

The toluene exposure model has important limitations. First, the categorical variables identified as determinants of exposure do not reflect the complexity of workplaces. Thus, in coding the type of paint used, we noted that, in many circumstances, painters used both solvent- and water-based paints during exposure monitoring. The paint type was coded on the basis of the predominant paint type used (by mass or volume), and therefore the observed contrast between different paint types is probably an underestimate of the true differences. The classification of paints into only two types of paints is, in itself, rather crude, as it may not reflect toxicologically relevant differences in hydrocarbon emissions. It is also likely that the composition of paint and the patterns of use of paint thinners by painters have varied through time. Second, the estimation of the effect of local exhaust ventilation was confounded by its being used when exposures were expected to be high (such as in confined spaces in the hull of ships). Third, we did not observe any differences between exposure levels during painting in large rooms and outdoors. This result may reflect the fact that, at present, the use of solvent-based paint is permitted in outdoor applications but not in indoor applications in The Netherlands. In any case, in the questionnaire administered as part of the health surveillance program, painting outdoors and the use of local exhaust ventilation are combined into one question. Not having separate estimates of the effects of these factors should therefore not hinder the exposure reconstruction effort.

The validity of the exposure trends that we observed was impossible to assess because we were not able to locate suitable quantitative exposure data. This lack of data is not surprising since, as far as we have been able to ascertain, this report is the first comprehensive study of exposure trends among painters.

We observed that the single-cell model did not adequately describe exposures among painters. However, 
we identified a stronger-than-expected positive effect of source strength; this result indicates that efforts to reduce exposure should be focused on altering that factor. The protective effect of ventilation on exposure levels was not observed, probably because (i) ventilation was increased by the painters in anticipation of high exposures and (ii) the configuration of ventilation systems (mostly general ventilation by opening doors and windows) was not adequate to achieve exposure reduction. It has been reported that "good ventilation . . . is often difficult to achieve in construction work [p 266]" (25). It is also possible that errors in the estimation of the effective air exchange (the applied methods in the survey were admittedly crude) prevented us from observing the true effect of ventilation on the exposure levels. Nonetheless, we did not observe the protective effect of general mechanical ventilation and strong natural drafts that was reported by Riala et al (25), even though there was almost a 100-fold range in airflow rates in our study. In general, our experience indicates that caution is advised in the application of simple deterministic models to assess exposures. Our results confirmed that more sophisticated physical models are needed to predict exposures during painting, such as those developed for solvent exposure during spray painting by inhalation (26) and by dermal uptake $(27,28)$. Deviations of predictions of single-cell models from real exposures were also shown in numerical simulations to be greatly dependent on both ventilation rate and type of exposure source (constant or varying strength) (29). However, for most epidemiologic applications, such as the one our study was catering to, more sophisticated models are not applicable due to the lack of sufficiently detailed production records. Future efforts to lower hydrocarbon exposure among painters should focus on the reduction of source strength and focus equally on the volume of paint used and its formulation (reduction of concentration of toxic substances in paint and use of paint components of lower vapor pressure). The use of low-vapor-pressure substances in paint, however, should be considered in conjunction with the consideration of concerns about the exposure of eventual space occupants to low-vapor-pressure substances.

In conclusion, using toluene as a proxy for total solvent exposure, we developed an exposure model that can be used to predict the intensity of inhalation exposure to aromatic solvents for the years 1980-1999 in a health surveillance program among commercial painters in The Netherlands.

\section{Acknowledgments}

A research grant from the Stichting ARBOUW (The Netherlands) funded the project.
This paper would not have been possible without the insightful discussions with Ton Spee and J Cor van Duivenbooden. The authors thank Con Boeckhout, Derk Brouwer, Marc Ruyten, Siebrand Veenstra, and Wies Hontelez for digging into their archives and Harro Hokse, Koen Sturm, Frans Jongeneelen, Theo Scheffers, MJ Pool, JBJ Gryglicki, and Simone Hilhorst for collecting the measurements. Pamela Cruise edited the manuscript. The authors are indebted to all the painters who took part in the exposure surveys.

\section{References}

1. Feldman RG, Ratne MH, Ptak T. Chronic toxic encephalopathy in a painter exposed to mixed solvents. Environ Health Perspect 1999;107(5):417-22.

2. Bruhn P, Arlien-Soborg P, Gyldensted C, Christensen EL. Prognosis in chronic toxic encephalopathy. A two-year follow-up study in 26 house painters with occupational encephalopathy. Acta Neurol Scand 1981;64(4):259-72.

3. Arlien-Soborg P, Bruhn P, Gyldensted C, Melgaard B. Chronic painters' syndrome. Chronic toxic encephalopathy in house painters. Acta Neurol Scand 1979;60(3):149-56.

4. Sliwinska-Kowalska M, Zamyslowska-Szmytke E, Szymczak W, Kotylo P, Fiszer M, Dudarewicz A, et al. Hearing loss among workers exposed to moderate concentrations of solvents. Scand J Work Environ Health 2001;27(5):335-42.

5. Xiao G, Pan C, Cai Y, Lin H, Fu Z. Effect of benzene, toluene, xylene on the semen quality of exposed workers. Chin Med J (Engl) 1999;112(8):709-12.

6. de Roos AJ, Olshan AF, Teschke K, Poole C, Savitz D, Blatt $\mathrm{J}$, et al. Parental occupational exposures to chemicals and incidence of neuroblastoma in offspring. Am J Epidemiol 2001;154(2):106-14.

7. Dick F, Semple S, Chen R, Seaton A. Neurological deficits in solvent-exposed painters: a syndrome including impaired colour vision, cognitive defects, tremor and loss of vibration sensation. QJM 2000;93(10):655-61.

8. Chen R, Dick F, Semple S, Seaton A, Walker LG. Exposure to organic solvents and personality. Occup Environ Med 2001;58(1):14-8.

9. Triebig G, Nasterlack M, Hacke W, Frank KH, Schmittner H. Neuropsychiatric symptoms in active construction painters with chronic solvent exposure. Neurotoxicology 2000; 21(5):791-4.

10. Axelson O, Hane M, Hogstedt C. A case-referent study on neuropsychiatric disorders among workers exposed to solvents. Scand J Work Environ Health 1976;2(1):14-20.

11. Mikkelsen S. A cohort study of disability pension and death among painters with special regard to disabling presenile dementia as an occupational disease. Scand J Soc Med Suppl 1980;16:34-43.

12. Schwartz DA, Baker EL. Respiratory illness in the construction industry. Airflow obstruction among painters. Chest 1988;93(1):134-7.

13. Hageman G, van der Hoek J, van Hout M, van der Laan G, Steur EJ, de Bruin W, et al. Parkinsonism, pyramidal signs, polyneuropathy, and cognitive decline after long-term occupational solvent exposure. J Neurol 1999;246:198-206.

14. Halifeoglu I, Canatan H, Ustundag B, Ilhan N, Inanc F. 
Effect of thinner inhalation on lipid peroxidation and some antioxidant enzymes of people working with paint thinner. Cell Biochem Funct 2000;18(4):263-7.

15. Hokse H, Sturm K. Beheersmaatregelen ter vermindering van blootstelling aan oplosmiddelen bij schilders [Measures to reduce exposure to solvents among painters]. Wageningen: Wageningen University, 1995. Internal report V380.

16. Jongeneelen FJ, Scheffers T. Arbeidshygienisch onderzoek naar de blootstelling van onderhoudsschilders aan oplosmiddelen [Occupational hygiene survey of exposure to solvents among house painters]. Wageningen: Wageningen University, 1982. Internal report 1982-113.

17. Hilhorst SKM; Vermeulen R; Kromhout H. Onderzoek naar de chronische blootstelling aan oploismiddelen, lasrook en zware metalen op de Rijkswerf [Survey of the chronic exposure to solvents, welding fumes and heavy metals at the Royal Navy shipyard]. Wageningen: Wageningen University, 2000. Internal report 2000-489.

18. Pool MJ, Veenstra SJ. Onderzoek naar de blootstelling aan verfdampen en mogelijke gezonheidseffekten bij scheepsschilders van de verenigde schilderscooperatie [Survey of exposures to solvents and possible health effects among shipyard painters]. Alkmaar: BGD 1984. Internal report of research project 8401 .

19. Veenstra SJ, Gryglicki JBJ, van Duivenbooden JC. Orienterend onderzoek naar de blootstelling aan oplosmiddeldampen bij het schilderen in kleine ruimtes [Survey of exposure to solvents among household painters painting in confined spaces]. Alkmaar: BGD, 1984. Internal report.

20. Boeckhout C. Schilderen achter afscherming [Painting behind screens]. Amsterdam: Dutch National Institute for Occupational Safety and Health in the Construction Industry, 1999. Internal report, Nov 1999.
21. Boleij JSM, Buringh E, Heederik D, Kromhout H, editors. Occupational hygiene of chemical and biological agents. Amsterdam: Elsevier Science BV, 1995:115-9. Exposure modelling, no 4.

22. Rappaport SM. Assessment of long-term exposures to toxic substances in air. Ann Occup Hyg 1991;35:61-121.

23. Fidler AT, Baker EL, Letz RE. Estimation of long term exposure to mixed solvents from questionnaire data: a tool for epidemiological investigations. $\mathrm{Br} \mathrm{J}$ Ind Med 1987;44:133-41.

24. Caldwell DJ, Armstrong TW, Barone NJ, Suder JA, Evans MJ. Hydrocarbon solvent exposure data: compilation and analysis of the literature. Am Ind Hyg Assoc J 2000;61(6):881-94.

25. Riala R, Kalliokoski P, Pyy L, Wickström G. Solvent exposure in construction and maintenance painting. Scand J Work Environ Health 1984;10:263-6.

26. Tan YM, Flynn MR, Buller TS. A field evaluation of the impact of transfer efficiency on worker exposure during spray painting. Ann Occup Hyg 2002;46(1):103-12.

27. Brouwer DH, Semple S, Marquart J, Cherrie JW. A dermal model for spray painters. Part I: subjective exposure modelling of spray paint deposition. Ann Occup Hyg 2001;45(1):15-23.

28. Semple S, Brouwer DH, Dick F, Cherrie JW. A dermal model for spray painters. Part II: estimating the deposition and uptake of solvents. Ann Occup Hyg 2001;45(1):25-33.

29. Bennett JS, Feigley CE, Khan J, Hosni MH. Comparison of mathematical models for exposure assessment with computational fluid dynamic simulation. Appl Occup Environ Hyg 2000;15(1):131-44.

Received for publication: 10 June 2002

\section{Appendix 1}

SAS 6.12 code for fitting data to a deterministic single-cell model: $e=$ exposure concentration; $s=$ source strength, $q=$ ventilation rate, beta 1 and beta2 are model parameters $\beta_{1}$ and $\beta_{2}$, respectively. The two "test" statements request Wald tests to be performed, producing the probabilities that $\beta_{1}$ and $\beta_{2}$ are equal to 1 and -1 , respectively:

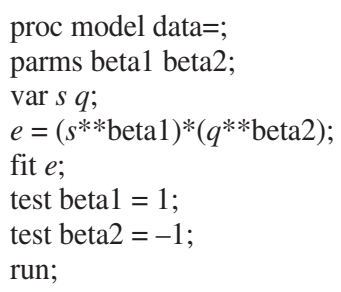

\section{Appendix 2}

The predicted median of the long-term between-worker distribution of average exposure intensity measured as milligrams of toluene per cubic meter is as follows:

\footnotetext{
$X=\operatorname{Exp}[-2.84-0.12 \times($ years since 1980$) \times($ solvent-based paint: 1 if yes, 0 if paint not used $)+2.82 \times$ (solvent-based paint: 1 if yes, 0 if paint not used) $+0.74 \times$ (water-based paint: 1 if yes, 0 if paint not used) $-2.25 \times$ (shipyard: 1 if yes, 0 if house paining $)+1.68 \times$ (spray-painting: 1 if yes, 0 otherwise $)+$ $0.45 \times$ room $<50 \mathrm{~m}^{3}: 1$ if yes, 0 otherwise $\left.)+0.5 \times 2.22\right]$.
} 
In order to translate these predictions into a mean exposure intensity for a given year, we had to take into account the variability in the work performed over the time interval (eg, both water- and solvent-based paints could have been used by a painter in a given year). Thus we calculated the median of the mean exposure $\left(M_{j}\right)$ for a worker who experienced $N$ exposure scenarios $\left(S_{I j}, S_{2 j}, \ldots S_{i j} \ldots S_{N j}\right)$ in a given year $(j)$ according to the following formula:

$$
M_{j}=\Sigma\left\{X_{i j} \times f\left(S_{i j}\right) \times\left(1-P F_{i j}\right)\right\} \text { for all } S_{i j} \text { that fall into the time interval/year }(j),
$$

where $X_{i j}$ represented the median value of the long-term means of individual exposures of a group of workers who experienced exposure scenario $S_{i j}$ in a given interval ( $j$ ) (ie, prediction of the multiple linear regression model, equation 1), $f\left(S_{i j}\right)$ was the frequency of scenario $i$ during time interval $j$, such that $\Sigma f\left(S_{i j}\right)=1$ for a given $j$, and $P F_{i j}$ is the protection factor for a respirator worn during exposure scenario $S_{i j}(0$ for dust mask, 0.65 for cartridge respirator, and 0.90 for air-supplied respirator). 